\title{
Standardization of metachromatic staining method of myofibrillar ATPase activity of myosin to skeletal striated muscle of mules and donkeys ${ }^{1}$
}

\author{
Flora H.F. D’Angelis ${ }^{2 *}$, Guilherme C. Ferraz ${ }^{2}$, Elis B. Santos², Matheus F.L. Steque², \\ Walter H. Feringer-Junior ${ }^{2}$ and Antonio Queiroz-Neto ${ }^{2}$
}

\begin{abstract}
D’Angelis F.H.F., Ferraz G.C., Santos E.B., Steque M.F.L., Feringer-Junior W.H. \& Queiroz-Neto A. 2014. Standardization of metachromatic staining method of myofibrillar ATPase activity of myosin to skeletal striated muscle of mules and donkeys. Pesquisa Veterinária Brasileira 34(9):917-922. Laboratório de Farmacologia e Fisiologia do Exercício Equino, Faculdade de Ciências Agrárias e Veterinárias, Universidade Estadual Paulista, Via de acesso Prof. Paulo Donato Castellane s/n, Jaboticabal, SP 14884-900, Brazil. E-mail: floradan@ig.com.br

This study aims at standardizing the pre-incubation and incubation $\mathrm{pH}$ and temperature used in the metachromatic staining method of myofibrillar ATPase activity of myosin (mATPase) used for asses and mules. Twenty four donkeys and 10 mules, seven females and three males, were used in the study. From each animal, fragments from the Gluteus medius muscle were collected and percutaneous muscle biopsy was performed using a 6.0-mm Bergström-type needle. In addition to the metachromatic staining method of mATPase, the technique of nicotinamide adenine dinucleotide tetrazolium reductase (NADH-TR) was also performed to confirm the histochemical data. The histochemical result of mATPase for acidic pre-incubation $(\mathrm{pH}=4.50)$ and alkaline incubation $(\mathrm{pH}=10.50)$, at a temperature of $37^{\circ} \mathrm{C}$, yielded the best differentiation of fibers stained with toluidine blue. Muscle fibers were identified according to the following colors: type I (oxidative, light blue), type IIA (oxidative-glycolytic, intermediate blue) and type IIX (glycolytic, dark blue). There are no reports in the literature regarding the characterization and distribution of different types of muscle fibers used by donkeys and mules when performing traction work, cargo transportation, endurance sports (horseback riding) and marching competitions. Therefore, this study is the first report on the standardization of the mATPase technique for donkeys and mules.
\end{abstract}

INDEX TERMS: Standardization, metachromatic staining method, myofibrillar ATPase activity of myosin, skeletal striated muscle, mules, donkeys, histochemistry.

RESUMO.- [Padronização do método de coloração metacromático da atividade da miosina ATPase miofibrilar para músculo estriado esquelético de muares e asininos.] $\mathrm{O}$ presente estudo objetivou padronizar o $\mathrm{pH}$ e a temperatura da pré-incubação e incubação do método de coloração metacromática de myofibrillar atividade ATPase da miosina (mATPase) utilizada para asininos e muares.

\footnotetext{
${ }^{1}$ Received on October 10, 2013.

Accepted for publication on July 27, 2014.

${ }^{2}$ Departamento de Morfologia e Fisiologia Animal (DMFA), Faculdade de Ciências Agrárias e Veterinárias (FCAV), Universidade Estadual Paulista (Unesp), Campus de Jaboticabal, Via de acesso Prof. Paulo Donato Castellane s/n, Jaboticabal, SP 14884-900, Brazil. E-mails: aqueiroz@fcav. unesp.br; *Corresponding author: floradan@ig.com.br
}

Vinte e quatro jumentos e 10 muares, sete machos e três fêmeas, foram usados no estudo. De cada animal, fragmentos do músculo Gluteus medius foram coletados e biópsia muscular percutânea foi realizada por meio de uma agulha Bergström tipo de 6,0 mm. Em adição ao método de coloração metacromática de mATPase, a técnica de nicotinamida adenina dinucleótido tetrazólio redutase (NADH-TR) foi também realizada para confirmar os dados histoquímicos. 0 resultado histoquímico da mATPase por pré-incubação ácida $(\mathrm{pH}=4,50)$ e incubação alcalina $(\mathrm{pH}=10,50)$, a uma temperatura de $37^{\circ} \mathrm{C}$, foi o que proporcionou a melhor diferenciação das fibras coradas com azul de toluidina. As fibras musculares foram identificadas de acordo com as seguintes cores: tipo I (oxidativa, azul claro), tipo IIA (oxidativo-glico- 
lítico, azul intermediário) e tipo IIX (glycolytic, azul escuro). Na literatura, não foram encontradas publicações pertinentes à caracterização e distribuição dos diferentes tipos de fibras musculares utilizadas pelos asininos e muares nos trabalhos de tração, no transporte de cargas, em provas esportivas de resistência (cavalgadas) e concursos de marcha. Dessa forma, essa pesquisa é o primeiro relato sobre padronização da técnica de mATPase para muares e asininos.

TERMOS DE INDEXAÇÃO: Coloração metacromática, atividade da miosina ATPase miofibrilar, músculo estriado esquelético, muares, asininos, histoquímica.

\section{INTRODUCTION}

Although the literature on methods of histochemical staining for skeletal striated muscle is extensive (Padykula \& Herman 1955, Guth \& Samaha 1969, 1970, Brooke \& Kaiser 1970, Olgivie \& Feeback 1990, Ennion et al. 1995, D’Angelis et al. 2005), the standardization of an efficient histochemical method suitable for skeletal striated muscle of donkeys and mules has not been reported yet.

Differentiation of fiber types in skeletal striated muscle can be based on the inhibition degree of the enzymatic activity of myosin myofibrillar adenosine triphosphatase (mATPase) following alkaline or acidic pre-incubation. This classical method was first developed by Padykula \& Herman (1955) and subsequently modified by Brooke \& Kaiser (1970) and Guth \& Samaha $(1969,1970)$.

To identify the different types of myofibers by histochemical techniques is necessary to compare staining intensities for distinguishing the types of fibers in transverse serial sections of the skeletal striated muscle, following incubation at different $\mathrm{pH}$, temperature and times. In this regard, several studies with different mammalian species have been published over the last twenty years such as dogs (Latorre et al. 1993), pigs (Fraga et al. 2009) and horses (D’Angelis et al. 2005).

The identification of three different types of fibers in skeletal muscle sections of humans stained with cationic dye following incubation with ATP in the presence of calcium was performed by Doriguzzi et al. (1983). These authors performed the steps pre-incubation at $\mathrm{pH} 4.5$ and incubation at $\mathrm{pH} 9.4$, followed by staining with azure $\mathrm{A}$ or toluidine blue. Using this technique, the authors were able to distinguish fibers type I (oxidative, stained dark blue), type IIA (oxidative-glycolytic, stained light blue) and type IIB (glycolytic intermediate blue staining).

Previous experiments showed that pre-incubation and incubation temperatures, as well as dehydration in alcohol of serial sections, can affect the conditions for the occurrence of metachromasia. In humans, Olgivie \& Feeback (1990) used pre-incubation at $\mathrm{pH} 4.5$ in the $22-24^{\circ} \mathrm{C}$ temperature range, with 10 seconds staining with toluidine blue and rapid washing in distilled water. Type I fibers were intensely stained blue-green, type IIB fibers were stained dark red and type IIC fibers were stained blue. When dehydrated in a series of increasing ethanol concentration, type I fiber remained blue-green, IIB fibers color changed to violet, type IIA fibers were stained light violet. According to the authors, this method allows to clearly distinguish the different types of muscle fibers.

D'Angelis et al. (2005) used the metachromatic staining method of myofibrillar ATPase activity of myosin for the identification of skeletal muscle fibers of athlete purebred Arabian (PSA) horses and standardized for this breed, the following: pre-incubation $\mathrm{pH}$ between 4.52 and 4.55 at a temperature $22-24^{\circ} \mathrm{C}$ while incubation $\mathrm{pH}$ varied between 10.50 and 10.55 at a temperature of $37^{\circ} \mathrm{C}$.

The concern about the lack of scientific information on this species and its hybrids has been the subject of scientific meetings and seminars. In the "World Equine Veterinary Association (WEVA)" Seminar held in India in 2011, in the section "The working horse and its wellbeing," one of the keynote addresses was about sustainable veterinary support for the mules in underdeveloped and developing countries (Trawford 2011). During the WEVA meeting held in 2013, our research group (D'Angelis et al. 2013) presented a preliminary study on the subject. Several studies related to donkeys and its hybrids in different areas of veterinary medicine have been published (Dugat et al. 2010, Latzel 2012, McLean et al. 2013, Kim et al. 2014). In our opinion, this study deals with a new and relevant subject since the population and use of donkeys and mules are significant in Brazil, as it can be seen on the websites of major breeders associations.

All propulsive force used by these animals to work is coordinated by muscle movements. In the literature, there are no published studies regarding the characterization and distribution of different types of muscle fibers used by donkeys and mules to perform traction work in cargo transportation, endurance sports (horseback riding) and marching competitions. In veterinary practice, it is important to characterize structural and biochemically the different types of skeletal muscle fibers, to monitor and diagnosis neuromuscular diseases. Furthermore, knowing the distribution and biochemical behavior of skeletal muscles of donkeys and mules that participate in physical activities enables to monitor and evaluate their fitness in order to train them more efficiently. The purpose of this publication was to standardize the $\mathrm{pH}$ and temperature of pre-incubation and incubation, as well as, the metachromatic staining method of myofibrillar ATPase activity of myosin for these animals.

\section{MATERIALS AND METHODS}

Twenty four donkeys (mean body weight $198 \pm 56.06 \mathrm{~kg}$ and mean age $46.80 \pm 3.12$ months and 10 mules, of which 7 females (mean body weight $224.25 \pm 33.54 \mathrm{~kg}$ and mean age $11.87 \pm 5.11$ months) and 3 males (mean body weight $276.67 \pm 70.06 \mathrm{~kg}$ and mean age $17.00 \pm 6.92$ months) were used in the study. The animals originated from a rearing facility in Orlândia, State of São Paulo, Brazil. A fragment of the Gluteus medius muscle was collected from each animal by the method of percutaneous biopsy using a 6.0mm Bergström-type needle (Lindholm \& Piehl 1974) following the procedure recommended by D'Angelis et al. (2005). The fragments of Gluteus medius muscle were removed at the same depth $(60 \mathrm{~mm})$ and prechilled by immersion in N-hexane for about 40 sec (Dubowitz 1985), kept frozen in liquid nitrogen, and later stored in a deep freezer (Biofreezer Forma Scientific, Instrucom Ind. Com. Ltda, SP, Brazil) at $-80^{\circ} \mathrm{C}$ until processed. The interval between obtaining and freezing biopsy specimens was 3 minutes to 
avoid methodological problems caused by muscle shrinkage that occurs when the biopsy is performed (Dubowits, 1985).

The histochemical analysis was used for identification and differentiation of oxidative, glycolytic and oxidative-glycolytic fibers, through the metachromatic staining methods of the mATPase activity of myofibers adapted from several authors as Olgivie \& Feeback (1990) and certain phases of the technique described by Guth \& Samaha (1970) and Ennion et al. (1995). Three cryosections, semi-serial $12-\mu$ m-thick cross-sections were cut in a cryostat (Micron GmbH - H1599 OM, 69190, Walldorf, Germany) at $-20^{\circ} \mathrm{C}$. Several slides were prepared containing three cross-sections each, from the same animal to determine the optimum $\mathrm{pH}$ for the pre-incubation and incubation.

After sectioning, the slides were kept at room temperature for 30 to 40 minutes for drying and adhesion to histological slide. Immediately thereafter, the sections were fixed for 6 minutes at 22$24^{\circ} \mathrm{C}$ in 5\% buffered formalin, pH 7.2 (pH-Metro Analion PM 608 Ind. e Com., Ribeirão Preto, Brazil) containing $0.17 \mathrm{M}$ sodium chloride, $336 \mathrm{mM}$ sucrose and $0.13 \mathrm{M}$ sodium cacodylate (Guth \& Samaha 1970). After successive washes in buffer 21mM TRIS-Base, pH 7.8, containing $3.4 \mathrm{mM}$ calcium chloride, the $\mathrm{pH}$ was adjusted with $5 \mathrm{~N}$ hydrochloric acid. Different pHs were tested in the pre-incubation and incubation steps. Five slides with the sections of each animal were pre-incubated at 5 different acidic $\mathrm{pH}$ values $(4.30,4.40,4.50$, 4.55 and 4.60 ) containing $52 \mathrm{mM}$ potassium acetate and $17.7 \mathrm{mM}$ calcium chloride for five to six minutes at a temperature between 22 and $24^{\circ} \mathrm{C}$ (Olgivie \& Feeback 1990). The slides with the sections were washed using the same buffer and the procedure described above. Subsequently, they were submitted to the second incubation step following the procedure described by Ennion et al. (1995), at five different $\mathrm{pHs}$ in an alkaline medium $(10.25,10.30,10.40,10.50$ and 10.55 ) containing $40 \mathrm{mM}$ glycine, $20 \mathrm{mM}$ calcium chloride and 2.5mM ATP (Sigma ${ }^{\circledR}$ Aldrich Chemistry of Brazil Ltd., São Paulo, $\mathrm{SP}$, Brazil) at $37^{\circ} \mathrm{C}$ for 25 minutes. Thus, 25 slides were analyzed for each animal. Further, the cuts were washed with distilled water and incubated in aqueous $1 \%$ calcium chloride for three minutes, washed again in distilled water, stained with $1 \%$ toluidine blue, dehydrated in a series of increasing ethanol concentration, diaphanized in xylene and mounted in entelan (Olgivie \& Feeback 1990).

The techniques of nicotinamide adenine dinucleotide tetrazolium reductase (NADH-TR), described by Novikoff et al. (1961) and indirect immunohistochemical method (D'Angelis et al. 2005) to stain fibers containing slow-contracting myosin (clone N0Q7.5.4D, Sigma ${ }^{\circledR}$ Aldrich, São Paulo, SP) were used to confirm the histochemical results of the myofibrillar mATPase.

\section{RESULTS AND DISCUSSION}

In recent years, worldwide, there has been a considerable increasing interest in studies involving mules and donkeys in various fields of veterinary medicine (Dugat et al. 2010,
Latzel 2012, McLean et al. 2013, Kim et al. 2014). In Brazil, there are a large number of associations for breeding and use of donkeys, especially mules. The southeastern states should be highlighted, especially Sao Paulo, with its ABPMEM (Associação Brasileira dos Proprietários de Muares e Equinos de Marcha) that organizes competitions in several categories, in addition to AMVALE (Assoc. dos Muladeiros do Vale do Paraíba), AMA (Assoc. Muladeiros de Avaré), AMV (Assoc. Muladeiros de Valinhos) and ACMB (Assoc. de Cavaleiros e Muladeiros de Boituva). These associations and others less active are responsible for a calendar of very competitive endurance and marching competitions. Still, in the southeastern, the newly created Associação dos Criadores de Jumentos e Muares Pêga of Rio de Janeiro (ACJMPERJ), the Associação Brasileira dos Criadores do Jumento Pêga with headquarters in Belo Horizonte (MG), the Associação dos Muladeiros de Itabira e Região and, the Associação dos Muladeiros de Unaí and Alto do Paranaíba (AMAP) are also highlighted. In the Midwest, where mules are intensively used to manage beef cattle, there are also very active associations that organize endurance and marching competitions such as Associação dos Muladeiros do Oeste Goiano (AMOG) and the Associação dos Muladeiros do Sudoeste Goiano (AMUSGO).

In this context, the scientific research of donkeys and mules involves the morphological determination of the main muscle fiber types and metabolic characteristics that may explain its adaptation to exercise and work. The standardization of this technique allowed us to identify clearly the different types of myofibers present in the biopsy fragment. The staining intensity result is different for each species; therefore, it is recommended to protocol mATPase staining technique by modifying the pre-incubation and incubation $\mathrm{pH}$ for each animal species. The main contribution of this study was to standardize the $\mathrm{pH}$ and temperature of the pre-incubation and incubation steps of the metachromatic staining method of myofibrillar ATPase activity of myosin using biopsy fragments of the Gluteus medius muscle. Would donkeys and their hybrids follow the same characterization pattern compared to horses? The activity of mATPase is known to be affected by many factors including time, temperature, $\mathrm{pH}$, buffer type, and ionic composition of the pre-incubation medium (Brooke \& Kaiser 1970a,b, Dubowitz 1985, Matoba et al. 1985). Therefore, a strict control of the technical procedure of mATPase histochemistry is necessary so comparisons between results from different laboratories are difficult or even nonsensical.

\section{Table 1. Activity of mATPase enzyme histochemically marked, indirect immunohistochemical and NADH-TR for the Gluteus medius muscle of donkey and mules}

\begin{tabular}{cccccc}
\hline $\begin{array}{c}\text { Types } \\
\text { of fibers }\end{array}$ & NADH-TR & $\begin{array}{c}\text { Contraction } \\
\text { feature }\end{array}$ & $\begin{array}{c}\text { Immuno- } \\
\text { histochemistry* }\end{array}$ & Histochemistry & $\begin{array}{c}\text { Contraction } \\
\text { feature }\end{array}$ \\
\hline I & Intense purple & Oxidative & Positive & $\begin{array}{c}\text { Light blue or } \\
\text { absence of color }\end{array}$ & Slow \\
IIA & $\begin{array}{c}\text { Intermediate } \\
\text { purple }\end{array}$ & $\begin{array}{c}\text { Oxidative } \\
\text { glycolytic }\end{array}$ & Negative & $\begin{array}{c}\text { Intermediate blue } \\
\text { IIX }\end{array}$ & Fight purple or \\
Glycolytic & Negative & Dark blue & Fast
\end{tabular}

*Slow-contracting myosin antibody. 
As described by Lindholm \& Piehl (1974), Guth \& Samaha (1969) and Olgivie \& Feeback (1990), the method of histochemical staining of myofibrillar mATPase activity using acidic pre-incubation ( $\mathrm{pH} 4.5$ ) and alkaline incubation ( $\mathrm{pH} 10.50)$ can appropriately classify the types of fibers I, IIA and IIX in skeletal muscle of horses.

The muscular fibers of the Gluteus medius of the mules and donkeys were identified according to the following staining technique in mATPase: type I (oxidative, light blue), type IIA (oxidative-glycolytic, intermediate blue) and type
IIX (glycolytic, dark blue), as shown in Table 1 and Figure $1 \mathrm{~A}, 2 \mathrm{~A}$ and $3 \mathrm{~A}$. In the NADH-TR technique for histochemical staining (Table 1, Fig.1C, 2C and D), type I fibers were stained deep purple, type IIA fibers had an intermediate purple color and the fibers IIX were not stained at all or displayed a very light purple. While in immunohistochemistry, slow contracting fibers (type I) and fast-contracting fibers (type II) were identified by golden-brown staining in the former and the absence of staining in the latter (Table 1, Fig.1D and 3B). The type differentiation of skeletal muscle
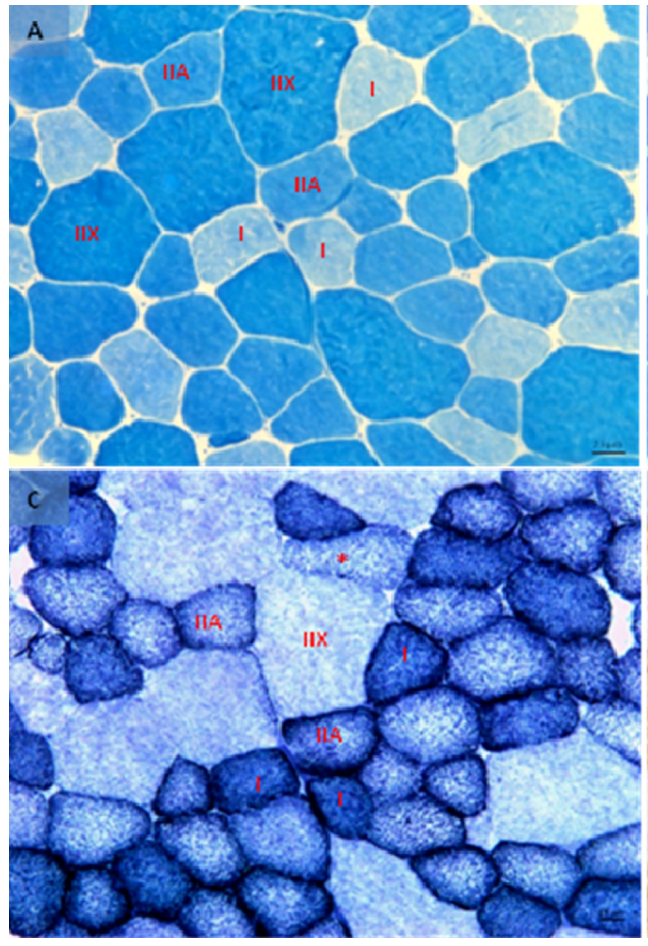
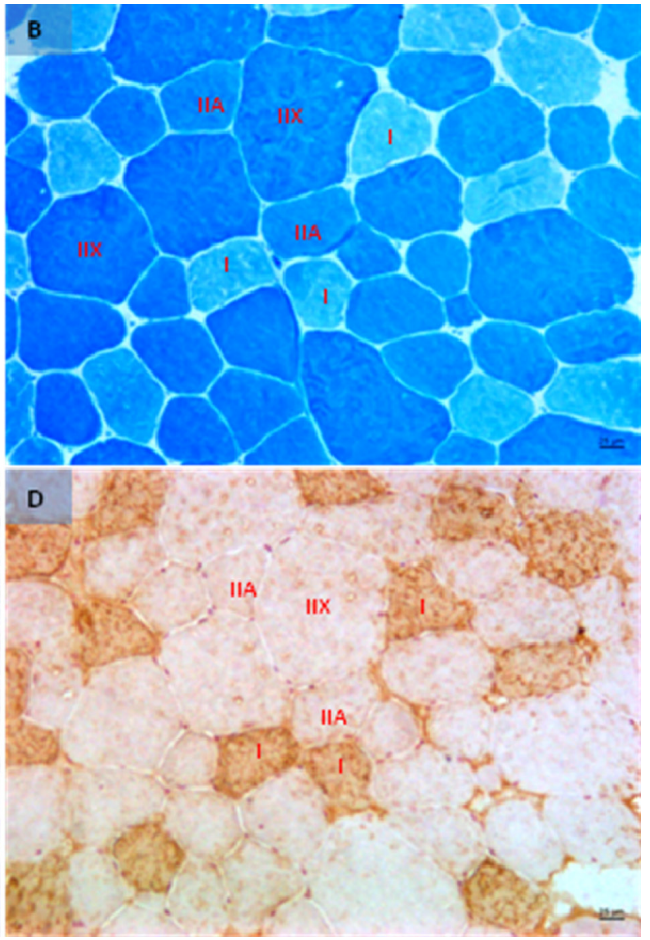

Fig.1. Serial histological cuts of the Gluteus medius muscle of a male mule. Cross-section of a mosaic of muscle fibers. (A) Staining of $\mathrm{mA}$ TPase activity after pre-incubation at $\mathrm{pH} 4.50$ and incubation at $\mathrm{pH}$ 10.50. (B) Staining of mATPase activity after pre-incubation at $\mathrm{pH}$ 4.45 and incubation at $\mathrm{pH} 10.50$. (C) Histochemical staining of NADH-TR. * Possible hybrid fiber IIA-IIX. (D) Immunohistochemistry for slow-contracting myosin. Fiber type I = brown, and type II = absence of staining, 200x.

Fig.2. Serial histological cuts of the Gluteus medius muscle of a female mule. Cross-section of a mosaic of muscle fibers. (A,B) Staining of mATPase activity after pre-incubation at $\mathrm{pH} 4.50$ and incubation at $\mathrm{pH}$ 10.50. (C,D) Histochemical staining of NADH-TR, 200x.
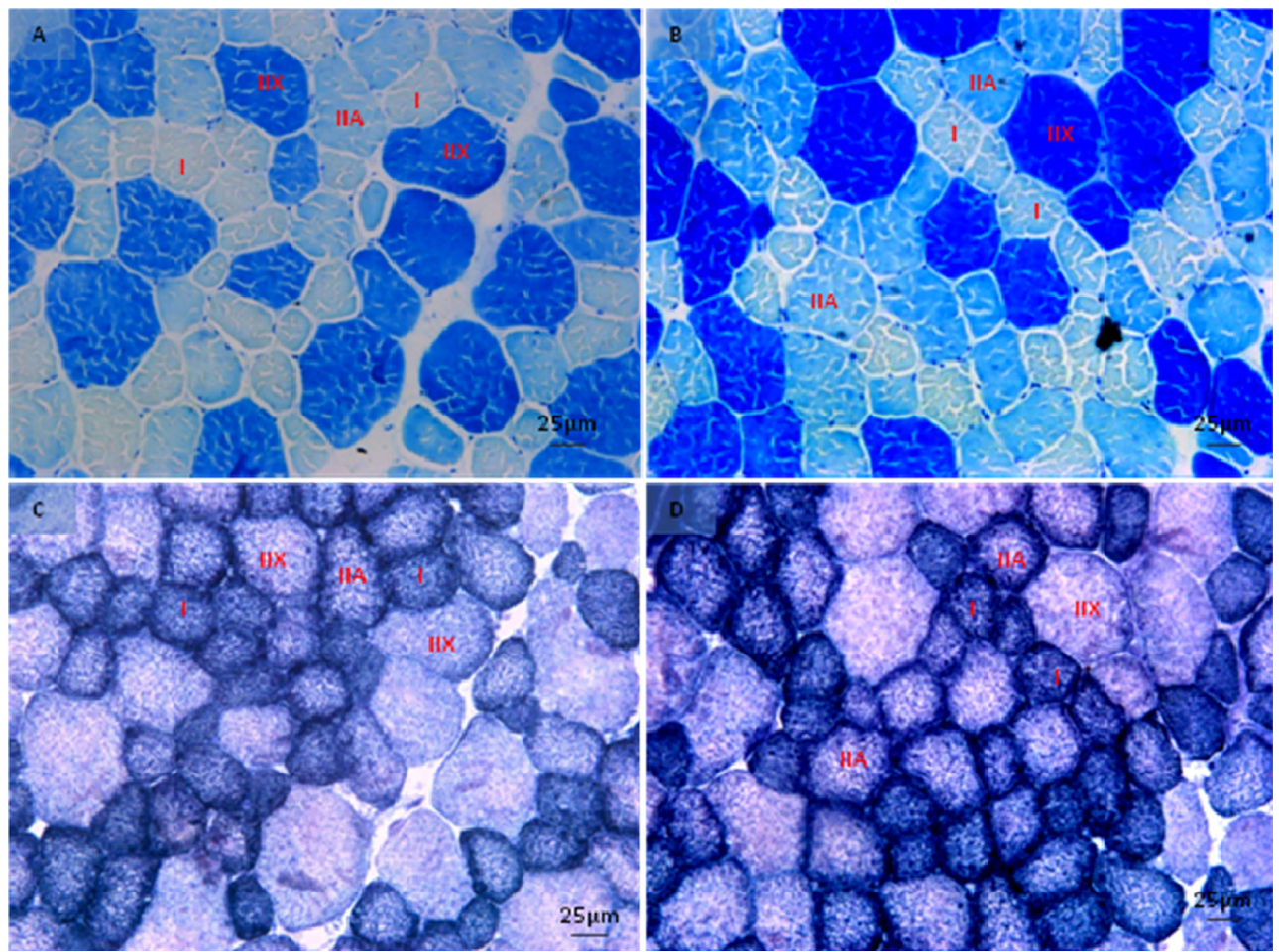
fibers is commonly based on the relative inhibition degree of myofibrillar mATPase activity, following alkaline and acidic pre-incubation. Olgivie \& Feeback (1990) also reported that the change of color intensity depends on pre-incubation and incubation temperatures, as well as on the intensity and deposition of calcium phosphate within each fiber. In addition to other factors already discussed above, the staining results are obtained according to the reaction of the chromotrope used to prepare the solutions with the mATPase enzyme (Olgivie \& Feeback 1990, Dimove \& Tasic-Dimove 2008). Guth \& Samaha (1969) argue that a given concentration of potassium ion in mATPase pre-incubation or incubation solutions results in a lower coloration intensity of type I fibers, when the pre-incubation medium is acid. The pre-incubation protocol used potassium acetate, thus justifying the results of this study for oxidative type I fibers, which showed a clear blue stain for toluidine blue. The potassium ion in this case inhibits the mATPase activity.

Olgivie \& Feeback (1990), in order to confirm that the staining obtained by Doriguzzi et al. (1983) in different types of fibers with Azure A and toluidine blue metachromatic stain solutions provide optimal conditions for a simultaneous display of different types of fibers reported that all pre-incubation and incubation conditions tested were satisfactory for analyzing the different types fibers. However, the solutions pre-incubated at acidic $\mathrm{pH}$ of 4.5 and room temperature $\left(22\right.$ to $\left.24^{\circ} \mathrm{C}\right)$ followed by incubation at $\mathrm{pH} 9.4$ and temperature $37^{\circ} \mathrm{C}$, as described in detail by Guth \& Samaha (1970), produced the best staining results to differentiate the types of fibers.

The histochemical results for acidic pre-incubation $(\mathrm{pH}$ 4.50) and alkaline incubation (10.50), at the temperature of $37^{\circ} \mathrm{C}$, stained with toluidine blue provided the best fiber differentiation. When $\mathrm{pH} 4.45$ was used in the pre-incubation (Fig.1B), it was difficult to differentiate IIA and IIX fibers because these fibers staining intensity were almost identical.

D'Angelis et al. $(2005,2008)$ used the same $\mathrm{pH}$ and temperature of pre-incubation and incubation in Arabian and Brasileiro de Hipismo horse breeds, obtaining similar results. Different results were observed with samples of muscles from rodents and cats by Guth \& Samaha (1969) and the human species by Olgivie \& Feeback (1990). These authors have obtained an intense staining for type I fibers at the same pre-incubation $\mathrm{pH}$ described by Ennion et al. (1995) but with modified incubation temperature and $\mathrm{pH}$.

When comparing the histochemical technique of the incubation phase for other species, Toniollo et al. (2007) reported for dogs, $\mathrm{pH}$ from 4.35 to 4.55 for determining type I fiber and the combination of $\mathrm{pH} 4.55$ and 10.4 for types IIA and IIB. For pigs, Fraga et al. (2009) determined the three fiber types using only incubation at $\mathrm{pH}$ 10.5. Another important issue that can be discussed refers to staining methods that use substances with barbital sodium in the formula (Padykula \& Herman 1955, Dubowitz 1985), which, in many countries, requires an authorization issued by local regulatory authorities prior to acquisition thus, hampering its use. Moreover, the standardization of the metachromatic staining method of the myofibrillar mATPase activity
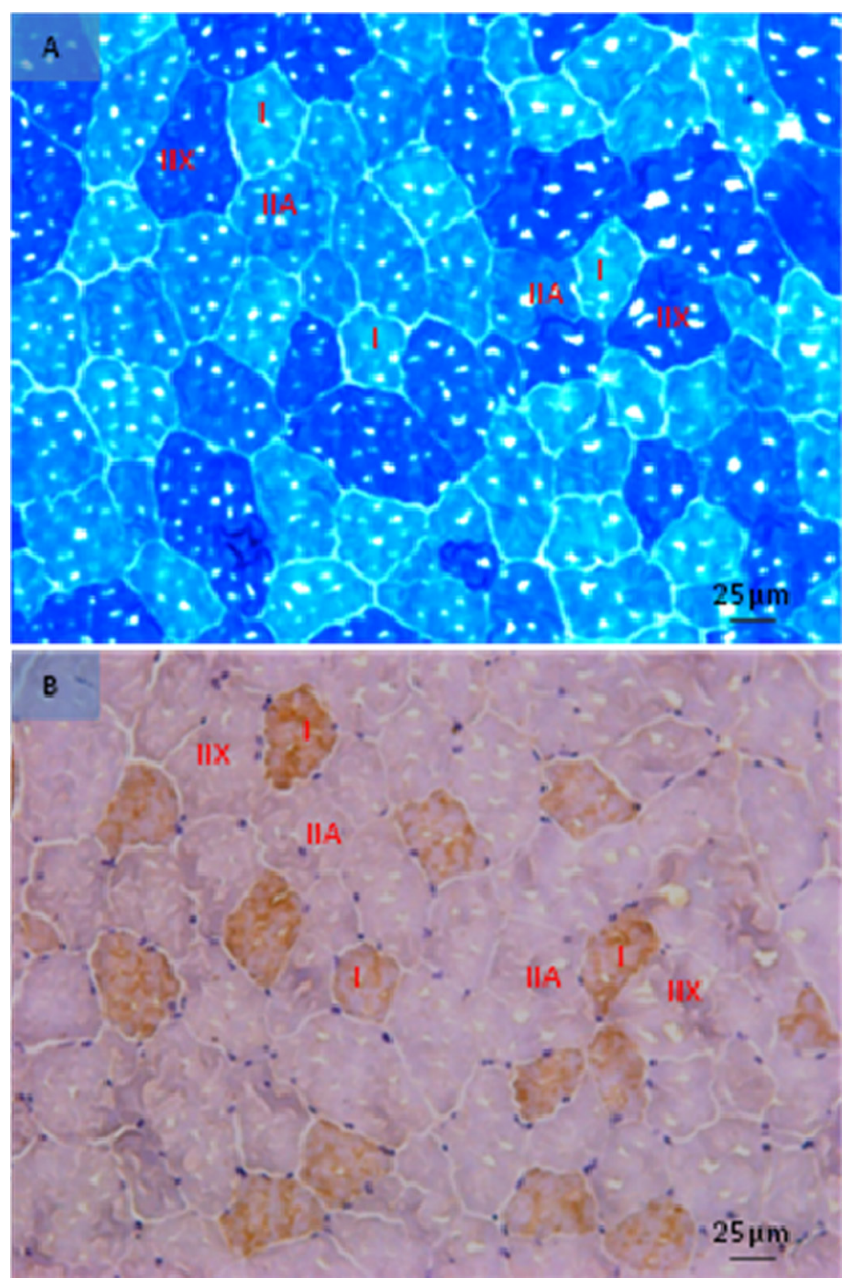

Fig.3. Serial histological cuts of the Gluteus medius muscle of asinine. Cross-section of a mosaic of muscle fibers. (A) Staining of mATPase activity after pre-incubation at $\mathrm{pH} 4.50$ and incubation at $\mathrm{pH}$ 10.50. (B) Immunohistochemistry for slow-contracting myosin. Fiber type $\mathrm{I}=$ brown, and type $\mathrm{II}=$ absence of staining, 200x.

was efficient. The method provided good visualization of cell contour and crisp and perfect different shades of blue, which is not seen when staining with sodium barbital.

\section{CONCLUSIONS}

The mATPase histochemical method of acidic pre-incubation $(\mathrm{pH}=4.50)$ and alkaline incubation $(\mathrm{pH}=10.50)$, at a temperature of $37^{\circ} \mathrm{C}$, was able to differentiate the myofibers stained with toluidine blue; and these histochemical results were further compared with the NADH-TR and immunohistochemistry techniques.

The method based on the use of cationic dyes in mATPase reaction is fast and easy, and can be used as an alternative to the conventional multiple steps mATPase method.

Acknowledgements.- To the National Research Council (CNPq) for the postdoctoral scholarship.

\section{REFERENCES}

Brooke M.H. \& Kaiser K.K. 1970a. Muscle fiber types: How many and what kind? 1970. Arch. Neurol. 23:369-379. 
Brooke M.H., Kaiser K.K. 1970b. Three myosin adenosine triphosphatase systems. The nature of their $\mathrm{pH}$ lability and sulfhydryl dependence. J. Histochem. Cytochem. 18:670-672.

D’Angelis F.H.F., Ferraz G.C., Boleli I.C., Lacerda-Neto J.C. \& Queiroz-Neto A. 2005. Aerobic training, but not creatine supplementation, alters the gluteus medius muscle. J. Anim. Sci. 83:579-85.

D’Angelis F.H.F., Silva M.A.G., Albernaz R.M., Ferraz G.C., Boleli I.C., Lacerda-Neto J.C., Oliveira J.A., Oliveira J.V. \& Queiroz-Neto A. 2008. Preliminary study on age- and sex-dependent alterations in the composition of skeletal muscle fibers of Brasileiro de Hipismo horses. J. Equine Vet. Sci. 28:22-27.

D’Angelis F.H.F., Steque M.F.L., Ferraz G.C., Santos E.B., Feringer-Junior W.H., Silva M.A.G., Queiroz-Neto A. 2013. Incipient study of skeletal muscle fiber composition of mules: a comparison between genders. Anais $13^{\text {th }}$ WEVA, Budapeste, Hungria. Means of disseminating on CD. (Abstract)

Dimov I. \& Tasic-Dimov D. 2008. Identification of fiber types In rat skeletal muscle based on the use of cationic dyes In myofibrillar adenosine Triphosphatase reaction. Acta Fac. Med. Naiss 25: 41-45.

Dugat S.L., Taylor T.S., Matthews N.S. \& Gold J.R. 2010. Values for triglycerides, insulin, cortisol, and ACTH in a herd of normal donkeys. J. Equine Vet. Sci. 30:141-144.

Doriguzzi C., Mongini T., Palmucci L. \& Schiffer D. 1983. A new method for myofibrilar $\mathrm{C}^{++}$-ATPase reaction based on the use of metachromatic dyes: its advantages in muscle fibre typing. Histochemistry 79:289-294.

Dubowitz V. 1985. Muscle Biopsy: a practical approach. $2^{\text {nd }}$ ed. Bailliére Tindall, London. 270p.

Ennion S., Sant'Ana P.J., Sargeant A.J., Young A. \& Goldspink G. 1995. Characterization of human skeletal muscle fibres according to the myosin heavy chains they express. J. Muscle Res. Cell Motil. 16:35-43.

Fraga A.L., Thomaz M.C., Kronka N.R., Budiño F.E.L., Huaynate R.A.R., Scandolera A., Ruiz J.U.S. \& D'Angelis F.H.F. 2009. Qualitative-feed-restricted heavy swine: meat quality and morpho-histochemical characteristics of muscle fibers. Braz. Archs Biol. Technol. 52:1145-1156.

Guth L. \& Samaha F.J. 1969. Qualitative differences between Actomyosin ATPase of slow and fast mammalian muscle. Exp. Neurol. 25:138-152.
Guth L. \& Samaha F.J. 1970. Procedure for the histochemical demonstration of actomyosin ATPase. Exp. Neurol. 26:120-125.

Kim T.W., Rocca G.D., Di Salvo A., Owen H., Sgorbini M. \& Giorgio M. 2014. Pharmacokinetics of the Novel Cyclooxygenase 2 Inhibitor Cimicoxib in Donkeys. J. Equine Vet. Sci. (In publication)

Latorre R., Gil F., Vázquez J.M., Moreno F., Mascarello F. \& Ramirez G. 1993. Skeletal muscle fibre types in the dog. J. Anat. 182:329-337.

Latzel S.T. 2102. subspecies studies: pharmacokinetics and pharmacodynamics of a single intravenous dose of xylazine in adult mules and adult Haflinger horses. J. Equine Vet. Sci. 12:816-826.

Lindholm A. \& Piehl K. 1974. Fibre composition enzyme activity and concentrations of metabolites and electrolytes in muscle of Standardbred horses. Acta Vet. Scand. 15:287-309.

McLean A.K. \& Wang W. 2013. Pilot study comparing hematologic and serum biochemical parameters in healthy horses (Equus caballus) and mules. J. Equine Vet. Sci. 33:353-354.

Matoba H., Allen J.R., Bayly W.M., Oakley C.R. \& Gollnick P.D. 1985. Comparison of fiber types in skeletal muscles from ten animal species based on sensitivity of the myofibrillar actomyosin ATPase to acid or copper. Histochemistry 82:175-183.

Olgivie R.W. \& Feeback D.L. 1990. A metachromatic dye-ATPase method for the simultaneous identification of skeletal muscle fiber types I, IIA, IIB, IIC. Stain Technol. 65:231-241.

Novikoff A.B., Shin W. \& Drucker J. 1961. Mitochondrial localization of oxidation enzymes: Staining results with two tetrazolium salts. J. Biophys. Biochem. Cytol. 9:47-61.

Padykula H.A. \& Herman E. 1955. The specificity of the histochemical method for adenosine triphosphatase. J. Histochem. Cytochem. 3:170-195.

Trawford A.F. 2011. Providing sustainable veterinary support for donkeys in deprived and developing communities. Anais $12^{\text {th }}$ WEVA, Hyderabad, India. Means of disseminating on CD. (Abstract)

Toniolo L., Maccatrozzo L., Patruno M., Pavan E., Caliaro F., Rossi R., Rinaldi C., Canepari M., Reggiani C. \& Mascarello F. 2007. Fiber types in canine muscles: myosin isoform expression and functional characterization. Am. J. Physiol. Cell. Physiol. 292:C1915-C1926. 